\title{
The School of Medicine of São Paulo in creating the Ribeirão Preto Medical School
}

\author{
Ricardo Brandt de Oliveira ${ }^{1}$, Helio Cesar Salgado ${ }^{1}$
}

$\mathrm{T}$ he foundation of the University of São Paulo (USP) in 1934 was an event of great impact, widely reported by the press, especially by the newspaper O Estado de São Paulo, which was read by the elites of the state of São Paulo. The idea of opening a university in the city of Ribeirão Preto began in the mid-40s. In 1947, prominent Ribeirão Preto area residents gathered to demand the creation of an institution of higher education. These citizens were encouraged by the speeches of the newly inaugurated Governor Adhemar de Barros in favor of the creation of a new university. As a result of this mobilization, the state legislator Luiz Augusto Gomes de Mattos proposed the creation of a Medical School in Ribeirao Preto (bill 37/1947). A few weeks earlier, the state legislator Miguel Petrilli had proposed the creation of a University in the city of Sao Carlos. At the end of extended discussions, the Legislative Congress of the State of São Paulo approved the creation of a Medical School in Ribeirão Preto and an Engineering School in Sao Carlos (law 161/1948) ${ }^{1}$. “...the FMRP was not simply created to confer a medical degree. Above all, it aspires to build a team of scientists, to encourage research and to create a center to spread knowledge in the field of medical sciences" (Zeferino Vaz, 1954)

During the same period, the USP proposed a major expansion to meet the increasing demand for the School of Medicine enrollments. This demand faced a major obstacle: the limited number of students was one of the conditions imposed by the Rockefeller Foundation for the support rendered to the School of Medicine in São Paulo city (FM-USP)*. This generous support would allow the construction of a grand set of buildings in the Pinheiros borough to serve as the campus for this medical school. In 1939, the FM-USP Council in response to this request, increased the enrollments by 10 students, with a total of 80 . However, the Council decision did not meet the society's demands. On March 4, 1940, the Governor of the State of São Paulo passed a Decree-Law (n $\left.{ }^{\circ} 10.967\right)$ and increased the enrollment to 200 students in the School of Medicine. In response, the University Council, however, on behalf of quality of teaching (according to the manifestations of Professor Renato Locchi and Paula Souza) and of moral commitment to the Rockefeller Foundation (Professor Aguiar Pupo) refused to meet the Governor's

* The other requirements made by the Rockefeller Foundation were full-time University teachers in basic areas and the construction of a teaching hospital; the latter requirement was fulfilled only in 1944.

1. Full Professor at Faculdade de Medicina de Ribeirão Preto da Universidade de São Paulo - FMRP-USP.

Mailing address: Ricardo B. Oliveira. Departamento de Clínica Médica, Faculdade de Medicina de Ribeirão Preto, USP. Av. Bandeirantes, 3900. 14048-900 - Ribeirão Preto, SP. e-mail: rbdolive@fmrp.usp.br 
determination, and maintained in 80 the number of students enrolled at FM-USP. It is worth mentioning that expressions of autonomy like this, which occurred during the Vargas dictatorship, and in response to a government designated governor, not an elected one, are increasingly rare in our academic institutions ${ }^{2}$.

The creation of a School of Medicine in the inland of the state of São Paulo was one of the solutions considered. Professor Ernesto Souza Campos, in this respect, declared on May $7,1947^{3}$ :

"This school is an exception; It is a jewel of Latin America ... It was created to confer degrees to doctors in quality, not in quantity. It would be more interesting to create a more simple medical school, maybe in an inland town, linked to our School, and under its scientific and pedagogical guidelines".

The first meeting of the committee in favor of the creation of the Ribeirão Preto Medical School and the University of São Paulo was held in May 1950. A group led by Paulo Gomes Romeo, President of the Medical Center of Ribeirão Preto, presented the existing facilities in Ribeirão Preto to settle the Medical School. Soon after, the President of the USP, Miguel Reale went to Ribeirão Preto. In fact, the whole process to establish a new university started in early 1951. On January 3, Professor Orlando Aidar, from the Department of Anatomy of the FM-USP, wrote a letter to Dr. Paulo G. Romeo to communicate that the project of opening a new medical school in Ribeirão Preto had stirred interest in his institution and a Commission had been formed to collect subsidies for the implementation of the project. In prompt response, Dr. Paulo Gomes Romeo suggested that the Commission should visit Ribeirão Preto and meet with the local Committee in favor of the School of Medicine. The meeting was held on February 15, 1951.

At that meeting, with the participation of the Mayor, José de Magalhães, and representatives of various sectors of local society, Professor Lourenço Roselino offered the facilities of the School of Dentistry and Pharmacy to the new University, "without any cost or obligations to the State". Similarly, Dr. Waldemar Pessoa offered the Maternidade Sinhá Junqueira, still under construction. The visiting commission, consisting of Professors Samuel Pessoa, Franklin de Moura Campos, Névio Pimenta, Mauro Pereira Barreto and Orlando Aidar, produced a considerable report in favour of establishing in Ribeirão Preto a new School of Medicine as a unit of the University of São Paulo (FMRP-USP). Since then, several actions followed, and on March 15, 1951, the process regarding the establishment of the FMRP-USP was forwarded by Dean Prof. Ernesto Leme to Prof. Zeferino Vaz to analyse and deliver an opinion to the University Council of USP.

Professor Zeferino was then a high-ranked Senior faculty member of USP. He became a member of the University Council in 1936, when he was elected Dean of the Veterinary Medical School and, fifteen years later, at the age of 43 years, he was the Chair of the Teaching and Guidelines Committee of the University. It should be emphasized that Prof Zeferino Vaz was a physician graduated from FM-USP, where he enrolled in 1926, the year that the academic structure of that institution was revised as part of the agreement made between the institution and the Rockefeller Foundation. As a freshman, Zeferino Vaz became interested in basic research and was introduced to Lauro Travassos and Ernesto Souza Santos, two researchers from Instituto Manguinhos, who started working at FM-USP attracted by the working conditions offered by that institution. The early scientific initiation, instructed by the parasitologist Lauro Travassos, paved the future career of Zeferino Vaz, which culminated into his appointment as Professor of the Department of Medical Zoology and Parasitology of the Veterinary Medical School - USP.

The relationship between Zeferino Vaz and Ernesto Souza Santos strengthened over time, and years later, Zeferino Vaz proclaimed himself as his "disciple and heir". Ernesto Souza Santos handled the negotiations between the Rockefeller Foundation and FM-USP ${ }^{4}$.

When he gave his opinion to the Teaching and Guidelines Committee, which was later approved by the University Council, Prof. Zeferino Vaz showed boldness. The document contained a full, carefully crafted proposal of how the FMRP-USP should be. Innovations that met the requirements issued by the Pan American Congress of Medical Education held in Lima (Peru), in 1951, were introduced in the curricular structure of FM-USP, which was taken as a model. Some traditional disciplines (Physics, and Organic Chemistry) were excluded and other disciplines considered innovative for the time (Preventive 
Medicine and Psychology) were then included. This gathering or fusion of related disciplines, which were traditionally dispersed in several chairs of Medical and Surgical Clinics, suggested the adoption of the departmental structure at FMRP-USP, although this academic regime was still in force at USP. Finally, full time was proposed to the entire faculty, which was considered an audacious initiative at that time.

On this occasion, Prof. Zeferino Vaz could probably foresee the key role he would play in establishing the new Medical School. As soon as his opinion was approved, Prof. Zeferino Vaz was appointed a member of the Executive Committee of FMRP-USP, created by the President of $U S P$ on October 1, 1951. Five days later, Prof. Zeferino Vaz handed in a draft for the implementation of FMRPUSP to the President of the National Council of Education, requesting authorization for the operation of the School of Medicine. Soon, he received a special credit (18 million cruzeiros) from the State Government, via USP President's Office to cover the expenses ${ }^{4}$.

In accordance with his repeatedly expressed proposal to create an important center for education and research, Prof. Zeferino Vaz spared no efforts to build a team of faculty members for the new school with highly qualified teachers, and who were willing to face the challenge of building the FMRP-USP. Taking advantage of his knowledge and contacts in the scientific world and probably taking the process of composition of the original faculty of USP that he observed closely, several pioneer teachers were brought from abroad. The success of this

\section{REFERENCES}

1. São Paulo (Estado). Assembleia Legislativa do Estado. Lei n.161, de 24.09.1948: dispõe sobre a criação de estabelecimentos de ensino superior no interior do estado. Diário Oficial do Estado de São Paulo, n.217, 26 set. 1948. Disponível em: http://www.al.sp.gov.br/norma/?id=30284.

2. Ata da Congregação da FMUSP, 04/03/1940, p.108. apud Mauro JEM, Nogueira AR. FMRP-USP - primeiros tempos, initiative can be measured by the key role played by Prof. Fritz Köberle (Austria), Lucien Lison (Belgium) and Miguel Covian (Argentina), who remained definitively in Ribeirão Preto.

Less remembered, but not less important is the fact this pioneer faculty mostly consisted of doctors who graduated from FM-USP, among them, the heads of the original Departments of Anatomy (Prof. Gerson Novah), Parasitology (Prof. Mauro Pereira Barreto), Surgery (Prof. Ruy Ferreira Santos), Internal Medicine (Prof. Helio Lourenço de Oliveira), Dermatology (Prof. Luiz Marino Bechelli), Obstetrics and Gynecology (Prof. Domingos Andreucci) and Preventive Medicine (Prof. José Lima Pedreira de Freitas).

According to Alberto Carvalho da Silva, ChairProfessor of FM-USP, Scientific Director (1968-69) and President (1984-1993) of FAPESP, “... The FMRP became one of the main centers for teaching and research at the University of São Paulo because Zeferino Vaz chose the right people and gave them autonomy to exercise their leadership functions".

The FMRP-USP received, since the beginning, significant contributions from $F M-U S P$, as emphasized by Dean Zeferino Vaz while addressing the graduates in 1957 “..The Ribeirão Preto Medical School is still and also the Casa de Arnaldo ${ }^{*} . .$. " and by the founder of the Department of Internal Medicine, Helio Lourenco, while addressing the graduates in 1958 "...If it is a presumption to think we intended to establish a model, we surely came prepared not to demerit the good standards...".

através dos documentos e pela voz de seus construtores. Ribeirão Preto: FUNPEC; 2004.

3. Ferraz JBF. Faculdade de Medicina de Ribeirão Preto: criação e impacto no ensino médico. Ribeirão Preto: FUNPEC; 2005.

4. Marinho MGSMC. Norte-americanos no Brasil: uma história da Fundação Rockefeller na Universidade de São Paulo (19341952). Campinas, SP: EDUSF; 2001.

*How the School of Medicine of USP is called by its students and former students. 